\title{
DOUBLE STANDARDS IN RECENT AMERICAN FOREIGN POLICY
}

\author{
TÜRKKAYA ATAÖV
}

\section{Introduction:}

A number of writers consider anarchy as the fundamental fact of international relations. ${ }^{1}$ Linked to the Hobbesian analogy, they see it as a chaotic arena of "war of all against all." The inference is that authority and order are lacking. Described as "political realism," this approach claims to analyze a number of social concepts such as human nature, interest, power and character of international affairs and exhibits a tendency to treat lack of democracy in relations between nations and even aggressive foreign policy as the inevitable products of reality, whether one likes it or not. It is deduced, then, that within this context, the history of international relations is, in fact, a struggle for domination. This pursuit, which may look to some commentators as a curtailment, raises the doctrine to the statús of a "universal truth." The bases of this interpretation are so widely described that they encompass, at times, theories of morality or social and economic doctrines. For instance, while an undemocratic leader of a client country may be portrayed as a statesman responsible to his people, another one, equally undemocratic or even duly elected by his citizens and responsive to their needs, may be presented in negative images. Similarly, laissez-faire between capital and labour in the domestic sphere and market economy in the international realm are the paradise of the economically strong.

${ }^{1}$ American theorists of successive generations who consider anarchy as being especially relevant to international politics are too many to be referred to in this article. I shall be content by giving a reference to a recent study that criticizes as well as summarizes these views: Helen Milner, "The Assumption of Anarchy in International Relations Theory: A Critique," Review of International Studies, London, 17 (1991), pp. 67-85. 
This approximation, which has had its dissidents and challengers, had been debated for a few decades. Numerous scholars, especially those who now share the "neo-realist tradition," are elevating the same concept of anarchy to the status of outstanding condition in the analysis of world politics. Most of these theories, expressed by past and present generations of writers, are particularly widespread in the United States of America. A history of that country's foreign relations shows that the sociological theories justifying the struggle for power and, in the final analysis, for hegemony acquire a particular feature in American politics. Such theories may make use of a wide range of other theories that conceal domination. It is no exaggeration to say that American foreign conduct is rather different from the one officially presented to the world. Some features of Washington's international behaviour are not widely known on account of suppression, neglect, ignorance or denial. Passive acquiescence contributes to this deception. Active dissent will help one see a contrast between policies made publicly known and actual applications.

There is no denial that power and violence have played a role in history in general and in international politics in particular. But a body of international laws and international governing institutions also exist. The examples that follow, namely, American policies in respect to some countries like Iraq, Lebanon, Palestine/Israel, Bosnia, Somalia, Libya, Grenada and Panama, as well as significant concepts such as nuclear weapons and the United Nations have elements of double standards that retard the quest for equality and democracy in relations among nations. Among other consequences, the end of the Cold War made issues between the North and the South grow more acute.

\section{The U.S. in the 1990s:}

Soviet tanks in some Eastern European capitals and later in Kabul, on the one hand, and U.S. subversion, aggression and state-run terrorism, on the other, were among the characteristics of the Cold War era. The domestic American counterpart of this policy was the entrenching of the militaryindustrial complex of which the former President Dwight D. Eisenhower (1953-61) complained in his farewell address. ${ }^{2}$ The mechanism of this system was high technology industry, developed by the taxpayer, who was moulded and controlled by a security ideology. While the Cold War enabled the leaders of the two conflicting blocs to maintain a fear of the other, the

\footnotetext{
${ }^{2}$ Noam Chomsky, Terrorizing the Neighborhood: American Foreign Policy in the Post-Cold War Era, San Francisco, AK Press-Pressure Drop Press, 1991.
} 
distribution of power gave the United States a chance to dominate parts of the Third World.

The Cold War has now ended between the main protagonists. The ideological barrier collapsed in the course of the past few years. But the Cold War is still continuing in the sense that the United States now has more elbow room in its quest for domination. The major threats to American interests are still the régimes, trying to be responsive to their people. As long as they have priorities other than the United States, such as the diversification of their economies, some words instead of "Communist", no longer in vogue, are being found for those foreign statesmen who get in the way.

Until the (second) Gulf War in late 1990 and early 1991, the U.S. military had two different concepts of strategic thinking. One concerned highintensity conflict, that is, a war with the Warsaw Pact countries fought with heavy weapons, theoretically including the nuclear ones as well, and the second, formulated to respond to guerilla warfare in some Third World nations, to be a low-intensity conflict, carried out with comparatively lighter weapons, which could be escalated, as in Vietnam, depending on the circumstances. Both of these alternatives had their own doctrines, strategy, tactics and weaponry.

The end of the Cold War changed this situation. Initially, the public thought that the new phenomenon would alter military thinking and organization radically, and that the needed sources of the nation could now flow into the non-military sector. After all, a European war of formerly anticipated intensity was out of the question. Presently, the U.S. needed only a fraction of the armed forces it had maintained in the past. Although this logic of the post-Cold War era should have been a release for the average man, it was not so for circles such as the professional military, the defence contractors and formulators of strategy, whose existence or function, depended on high spending for the armed forces.

It was the Gulf War that "legitimized" a new assertion of pax Americana. This is a renovated phenomenon, based on the concept of socalled "new enemies" which posses up-to-date conventional weapons, perhaps with some additional nuclear capability. Consequently, a mid-intensity conflict theory developed from this contention that substantial military power was still needed in the post-Cold War era. The new theory, which may be termed the "Bush Doctrine", met the requirements of the institutions and people whose livelihood depended on high military allocations. The removal of the "Vietnam syndrome" was the first hurdle that President George Bush had to overcome. 
Blocking democracy domestically in the United States is much more complex than doing the same in the international arena. This does not mean that there cannot be crises of democracy in the country, but an army massacre as it occurred in My Lai cannot be repeated at home. However, internationally, not only Panama's Manuel Noriega may be removed by invasion, but subsequent efforts may be seen as necessary to overcome the "Vietnam syndrome."

The Soviet Union apologized for its invasions in Eastern Europe and in Afghanistan. But the United States did not follow such a lead for its overt and covert interferences in Latin America, the overthrow of the democratic governments of Guatemala (1954) and Chile (1973), the invasion of South Vietnam and the Dominican Republic or the campaign of terrorism against Cuba. The withdrawal of Soviet support to actors of opposition to American policies gives the United States now more scope to impose its preferences.

However, while the United States longs for a chieftanship without a rival, it is constantly losing ground, this time, to Japan and Europe. ${ }^{3}$ It no longer has the economic power to influence the consequences of the transformation in the former Eastern bloc of nations. Germany, some other Western European nations, and Japan are utilizing this opportunity. The combined GNP of the European Common Market is as big as that of the United States. Japan's economy is the second largest of any nation in the Western world. Both are capturing, even in the United States, markets and technology for consumer goods that the Americans used to dominate. In the Pacific Rim, most of the Asian countries in the arc from Japan to Australia are now part of the economic boom that led to a combined GNP three-fourth as large as the United States or the European Common Market. Targeting industrial areas, including ground transportation, electronics, aviation, and ultimately space, the Japanese economy may capture the U.S. domestic markets over the long term.

\section{Double Standard vis-a-vis Iraq:}

Considering the general evaluation in the preceding paragraphs, it is no surprise, then, that the immediate goal of the bipartisan American war drive and the assault on Iraq was to change the relationship of forces in the Gulf region, install a new régime in Baghdad, outbid other Western competitors in the area, and realize a victory that, in the words of President George Bush (1989-93), would kick the "Vietnam syndrome once and for all." ${ }^{4}$ Iraq's

\footnotetext{
${ }^{3}$ S.J. Deitchman, Beyond the Thaw: A New National Strategy, Boulder, Westview Press, [1992], pp. 46-48.

${ }^{4}$ Quoted in Jack Barnes, "Washington's Assault on Iraq," New International, London, 7 (1991), p. 31.
} 
attack and invasion of Kuwait (1990) and the subsequent war could have been avoided. ${ }^{5}$ The United States was sending mixed messages to Iraq, giving the impression that military action against Kuwait would not provoke American retaliation. Apart from being full of falsehoods and phantasies, ${ }^{6}$ the war that ensued reveals double standards.

The Gulf crisis, the countdown, the battle and its aftermath are full of misinformation, misconceptions and omissions. Perhaps the most significant reality is that the American Government did not decide to go to war against Iraq in order to establish a "new world order", as so enunciated by the former President Bush. Just the opposite. The decision to escalate the confrontation to war was aimed at leaving the United States unrivalled as the only dominant power in the Middle East while there were other rivals regionally and internationally. Washington, which had generally supported Iraq against Iran during the first Gulf War (1980-1988), had the most to lose from a shift of power in the Gulf region.

The world was surprised at the efficiency that the U.S. military had exhibited. It was, indeed, the result of years of planning and funding, going back to the failure of the Nixon Doctrine (1969) and its replacement by the Carter Doctrine (1980). The former had declared that the future allies would deal with their own security with American weapons but without American troops. The fall of the Shan in Iran (1979) and the Soviet military presence in Afghanistan (1979) brought forth Carter's conception that the U.S. would react, including with armed force, to what it calls assaults against its own interests.

It was during Ronald Reagan's presidency (1981-89) that the construction program for new or expanded military bases became ambitious. For instance, virtually "military cities" grew in parts of Saudi Arabia, which led (1982) to the sale of $\$ 8.5$ billion worth of AWACS aircraft, the largest single arms deal in American history. If gave advantages to Saudi Arabia over Iraq, Iran and Yemen (but not over Israel). Apart from the fact that its operations, spare parts and maintenance required U.S. support, joint military exercises made the people in the region as well as the American public accustomed to the presence of U.S. troops there. Iran being then the main "enemy", neither the Iraqi attack on the U.S.S. Stark killing about forty American sailors, nor the allegation that Iraq used (1988) chemical weapons on the Kurds in Halapche motivated the American Government.

\footnotetext{
${ }^{5}$ For this view, see: Pierre Salinger with Erie Laurent, Secret Dossler: The Hidden Agenda Behind the Gulf War, London, Penguin, 1991.

${ }^{6}$ Dilip Hiro, Desert Shield to Desert Storm: The Second Gulf War, London, Paladin, 1992.
} 
The conditions changed when Iraq occupied Kuwait. President Bush had to win an ideological battle at home before any military action against Iraq. He aimed to "crush" two targets; the Vietnam syndrome at home and Iraq abroad. Grenada and Panama had been short episodes. Much more was needed to overcome the past legacy of Vietnam. The Congressional approval for war was marginal: 250 to 183 in the House and 52 to 47 in the Senate. The Reagan-Bush administration had protected Iraq, reversing sanctions in the House-until the Iraqi invasion of Kuwait. The American conflict was over oil. It was only later that the U.S. Government, basing its allegation on a State Department report, asserted that Iraq had poison-gassed the Kurds. But another study by the U.S. Army War College contradicted that statement. When the war came, it was a slaughter, American commanders referring to "turkey shoots". The mass media prevented the release of news that civilian targets were being hit. It was as if the war was fought over "real estate", not on people. The truth is otherwise.

It is true that Iraq invaded Kuwait but Israel also attacked Lebanon (1982). ${ }^{7}$ Although there are some differences in these two situations, they favour Iraq and the Palestinians. Iraq attacked Kuwait, which is of course an aggression, only after the failure to reach a negotiated settlement. Israel attacked Lebanon to avoid a compromise, when the Palestine Liberation Organization (PLO) was willing to negotiate with its adversary. A compromise would have meant an end to the régime in the occupied territories. Israel chose to attack. The United States did not show a response to Israel's invasion of Lebanon in any way similar to the one seen fit for Iraq.

The Israeli attack caused the death of some 20,000 people. A few hundred died on account of the Iraqi invasion. While both assaults caused death, there is a large numerical difference. Iraq admitted that it resorted to chemical weapons, outlawed and brutal, against against some of its adversaries. Israel denied, but nevertheless used various bombs and devices, considered criminal acts.

Iraq's action was invasion of a sovereign state, independent since mid1961. But it had a debatable claim since the time of Abdel Kerim Qassem (not Saddam Hussein), expressed only a few days after Kuwait's independence and based on its former (before 1899) status within the Ottoman vilayet (province) of Basra. British forces rushed to Kuwait, and the invasion from the north did not materialize. While the Iraqi claim is debatable, as a point of view that may or may not have a legal basis, Israeli expansion apparently could not be subject even to any discussion. Its origins are supposed to be in the Bible, and therefore, non-negotiable and permanent.

7United Nations, The Question of Palestine: 1979-1990, New York, 1991, pp. 7-10. 
It is true that Iraq ill-treated some of the civilian population in occupied Kuwait. Israel took 1200 hostages from Lebanon to guarantee the behaviour of the local people. Some property has been destroyed in Kuwait. But Israel wiped off the map hundreds of Palestinian villages.

President Bush took pride that the United Nations had finally united against the aggressor - Iraq. The same United Nations had united previously on a number of occasions, condemning Israeli aggression on Lebanon, its annexation of Jerusalem and the Golan Heights, its occupation of the West Bank and the Gaza Strip and its human rights violations. In each of these cases, Israel was either the only U.N. member casting a negative vote or was accompanied by the United States only. It was the United States alone that opposed Security Council draft resolutions threatening sanctions against Israel.

The six-week bombardment and one-hundred-hour invasion of Iraq by the United States (and its allies) devastated the country. The attacking forces conducted a militarized slaughter of simply defenseless Iraqis in uniform, abandoned in trenches, trying to flee Kuwait and return back home. They were not fighting, but fleeing people. The American forces bombed both ends of the highway from Kuwait city to Basra and sealed them off, and shot at almost every human being in between. If the names of all the victims should be written on granite walls, like the Washington memorial for the dead in Vietnam, they would stretch beyond the distance the naked eye can see.

When ex-President Bush visited Kuwait in early 1993, the police arrested there suspects, some of whom were Iraqis, and charged them with an alleged plot to assassinate the American statesman. The line of thinking seemed to be that Iraq wanted to "punish Bush" for having led the war against it. In June 1993, the United States launched missiles from its warships in the Red Sea in the direction of Iraq's capital, most of them striking the headquarters building of the Intelligence Service in Baghdad but some landing off target and killing civilians. President Bill Clinton's administration defended the American action on the basis of "self-defence", as response to an alleged Iraqi plot to kill the ex-president. Baghdad denied the charge.

But Article 51 of the U.N. Charter, which permits resort to force only in self-defence, introduces some limits and conditions as well. Self-defence is an acceptable concept, but its broad interpretation opens the door to aggression. Self-defence involves "hostilities", not a single murder. Moreover, whoever was involved, the attempt, if true, never reached its so-called aim. There was no attack. Even if it was planned, it was frustrated. Further, there was no evidence of similar Iraqi attacks in progress. So, it cannot even be "anticipatory self-defence", which is controversial in international law. Article 51 states that an "armed attack" should have occurred. This is not the 
case. The United States might have decided that way on its own, but this is usurping the functions of the U.N. Security Council. Further, the raid on Baghdad was not a proportional response. The U.N. Charter prohibits (Article 2/4) any resort to force, except in self-defence, provided that the case is really self-defence and in proper limits. States are obliged to settle their differences, moreover, by peaceful means only (Article 33). A. U.N. member cannot do what it wants, and then go to the Security Council, and use its veto privilege to stop a resolution condemning its action.

The outcome of the Gulf war contrasts with American invasions of Grenada (1983) and Panama (1989). In the case of the latter two, Washington carried through limited armed operations and imposed on both capitals servile administrations within record time. Whether or not the status quo in these two societies or in the whole of Latin America may be maintained in the future is another question. But military mastery was accompanied by immediate political triumph. Military success in Iraq, on the other hand, did not bring the same trophy. It set in motion, instead, new engagements and struggles.

Although seemingly waged behind the façade of a "broad international coalition," the war was a U.S. government operation. It gave the United States additional leverage over its rivals. For instance. England had to be content with a junior position in an area which was once a "British lake." France, which once enjoyed special ties with Baghdad, did not regain a better economic foothold. Japan is still dependent on imported oil. Turkey, Iraq's immediate northern neighbour, received serious economic blows from honouring the continuing blockade, which disconnects the flow of oil and funds from Iraq. None of the governments, save Iran and Turkey, which supported the American initiative in the Gulf, opened their borders to the refugees. Some, much later, agreed to accept only selected few families of symbolic nature.

While the American companies have been awarded the overwhelming majority of the reconstruction projects in Kuwait, the embargo on Iraq penalizes the people because it keeps food, water, medicine and other vital necessities away from them. There is a dramatic increase in the death rates especially of children and elderly people. With factories, irrigation works, electrical generation plants and various other facilities being destroyed, this was a total war, putting out of action almost everything that would help continue normal life.

\section{Double Standard in Nuclear Weaponry:}

The war on Iraq also uncovered the Baghdad régime's secret drive to become a nuclear power. The overwhelming majority of the governments, led by the United States, is against that, especially when it is known that Iraq 
had signed the Non-Proliferation Treaty (NPT). The same countries are sensitive over similar developments elsewhere, in North Korea for instance. But the United States treated Israel very differently. Israel, which did not sign the NPT and did not allow the International Atomic Energy Commission (IAEC) to carry out inspections on its territory, became a nuclear power in secret. This secret was sanctioned and shared by the top officials of the United States since the Eisenhower years.

Few writers in the West dwelled on Israel's nuclear arsenal. Some produced, nevertheless, insightful works on the development of that country's nuclear capability. ${ }^{8}$ David Ben-Gurion, Israel's Prime Minister and Defence Minister (1948-63), was quoted several times that his country would build an atomic reactor using its natural uranium and heavy water. While Israel had supporters in the U.S. Congress, several individuals led the pro-Israeli lobby to influence the American executive, there was a secret fund-raising for the Israeli bomb, and the Washington bureaucracy aided the Israeli effort in more ways than one.

Abraham Feinberg, an ardent Zionist who coordinated the fund-raising drive for President Harry S. Truman's (1945-53) campaign, was Ben-Gurion's most trusted ally in the United States. Lewis L. Strauss, a Jewish American who happened to be the chair-man of the U.S. Atomic Energy Commission and who had met, not only his Israeli counterpart Ernest David Bergman, but also Dr. Chaim Weizmann as early as 1930 , was approving Israel's nuclear program. A few of the Jewish American physicists, some of whom had worked in nuclear projects in the United States, went to Israel. Some of those who came back gave the CIA officials specific information on Israel's quest to have nuclear weapons. They also told that Israel was raising large amounts of money from the Jewish American community to be used for that purpose. The latter were already providing large amounts every year. But a particular group, known as the "Committee of Thirty", raised money for "special weapons" project. Some of these Jewish millionaires visited the Israeli nuclear works at Dimona after their completion. It was the United States that helped finance and fuel the first small reactor at Nahal Soreq near Telaviv.

The U-2 spying flights over Soviet territory also gave information on the Israeli nuclear activities in the Negev desert. The CIA developed and analyzed films from the U-2 missions and transmitted the results to President Eisenhower. The findings were also sent to the Jewish chairman of the U.S. Atomic Energy Commission. There is no doubt that the United States saw the Israeli construction at Dimona going up. While U-2 flights were going on, Israel was digging a second underground site for the chemical reprocessing plant to make weapons-grade plutonium. Evidence proved that

\footnotetext{
${ }^{8}$ For instance: Seymour M. Hersch, The Samson Option: Israel,
} America and the Bomb, London, Faber and Faber, 1993. 
Israel was determined to manufacture nuclear bombs. President Eisenhower and his advisors looked the other way.

All of the American administrations of the post-Eisenhower era were aware of the developments in Israel's nuclear capability. Only for President John F. Kennedy (1961-63), Dimona was an impediment for rapprochement with the Soviet Union and Nasser's Egypt, two of his foreign policy goals. But even his advisor on Jewish and Israeli affairs, Myer Feldman, visited Dimona in 1962 and knew that Israel was planning and preparing to build the bomb. Although this was the case, none of the Kennedy biographies, including the one by Arthur Schlesinger, offers information about Israel's quest for the nuclear bomb.

Israel never agreed to an IAEA inspection, but only to a "check up" by an American team, which was in fact a whitewash, the scheduled visit being announced well in advance, with no spot checks allowed and a control room constructed to mislead the investigators. President Lyndon B. Johnson's (1963-69) administration pretended that American inspection was proof enough that Israel was not manufacturing the bomb. With strong ties to Israel, Johnson was the first American president to give Israel offensive weapons, including F-4 Phantom fighter-bombers capable of carrying a nuclear bomb.

One product of such policies was the Israeli attack on three Arab neighbours in 1967. Walworth Barbour, the American ambassador in Telaviv, ordered his staff, after the Six-Day War, to stop reporting on nuclear weapons in Israel. Barbour later became a board member of the American branch of Bank Leumi, Israel's state bank. But by that time, Dimona was producing 4-5 warheads per year.

Successive American administrations tried to keep the lid on public knowledge of Israel's nuclear weapons project. There was also Israeli espionage inside the United States. For instance, a total of 572 pounds of highly enriched uranium vanished from the stocks of the Nuclcar Materials and Equipment Corporation of Apollo (Pennsylvania), founded by Dr. Zalman Mordechai Shapiro. This corporation was reportedly visited by Israeli technical staff, embassy officials and spies. ${ }^{9}$

Especially President Richard M. Nixon (1969-73) and his Secretary of State Henry A. Kissinger showed an extraordinary tolerance for a nuclear Israel. When Egypt attacked across the Sinai desert and Syria pushed into the

\footnotetext{
${ }^{9}$ Andrew and Leslie Cockburn, Dangerous Liaison: The Inside Story of the U.S.- Israeli Relationship, New York, Harper Collins, 1991, pp. 71-97.
} 
Golan Heights in 1973, everything initially seemed lost for Israel, which called its nuclear alert. Had it not received military aid from the United States, it would probably have resorted to nuclear means. The bombs were actually put in forward positions, to be taken back from there when the threat both in Sinai and the Golan Heights was removed. This had been the "Samson option," meaning that Israel was ready to extinguish itself and its enemies, just as Samson, according to the Bible, given back his strength for the last time, had brought down the temple pillars and the roof killing all, including himself. The American government chose not to speak about it even when the issue was debated inside Israel.

When America's first $\mathrm{KH}-11$, the satellite whirling around the world every ninety-six minutes and taking reconnaissance photographs, had been launched (1979), President Jimmy Carter (1977-81) provided Israel with aerial photographs, furnishing the latter with classified information on all potentially threatening movements one-hundred miles inside the borders of Syria, Lebanon, Jordan and Egypt. The limit being a certain distance, the information did not cover any activity inside Iraq, Libya or Pakistan. A high proportion of the top American officals anticipated at that time that the Israelis would do everything to surpass the limit.

Israel requested and received $\mathrm{KH}-11$ coverage of most of the European part of the Soviet Union. In other words, it had access to intelligence information far beyond the one-hundred mile limit, and no quarter in the United States monitored to see what Israel was actually doing and how it put that information into use. Israel bombed (1981) the Iraqi "Tammuz" (Osirak) reactor, twelve miles southeast of Baghdad, with the F-16s purchased from the United States for defensive purposes only. The bombing having caused wide protests, the American executive announced that further deliveries would be stopped, but more aircraft were released only two months later. In contrast to the Iraqi reactor, the Israeli complex was producing plutonium for nuclear weapons.

The world came to know about the details of the Dimona chemical reprocessing plant when the London Sunday Times printed the inside story of Mordechai Vanunu, a Moroccan Jew. ${ }^{10}$ When Israel launched its first satellite into orbit in late 1988, scientists, including the Americans, estimated that the same rocket booster had the capacity to send a nuclear warhead to targets more than six-thousand miles away. Israel now is believed to have a few hundred neutron warheads.

That country became a nuclear power with the knowledge, if not the collusion, of the United States, which shows utmost sensitivity when some

${ }^{10}$ October $5,1986$. 
other countries show tendencies to acquire the bomb. This is a double standard.

\section{Bosnia, Somalia and Palestine/Israel:}

Apart from Iraq, the world is going through crises in Bosnia, Somalia, and Palestine/ Israel. The reactions of the American government to each of these have been different and selective.

The "Moslems" of Bosnia-Herzegovina were one of the products of the Ottoman (Turkish) presence in the Balkans for about five centuries. They were classified as "Moslems" in former Yugoslavia, as one of the "peoples", along with the Serbs, Croats, Montenegrins, Macedonians and Slovenes. "Nationalities" (meaning minorities) and "ethnic groups" constituted other categories. The Turks, Albanians, and other Moslems fall into different groups. The Bosnian Moslems now face starvation, murder, assassination, mass rape, sniping at civilians, hindrances to humanitarian aid and defiance of the United Nations, on the part of the Serbs. For all intents and purposes, the State of Bosnia-Herzegovina, a member of the United Nations, is being dismantled while the world looks on. Few countries, among them Turkey, took initiatives to limit the extraordinary drama. The delay in the case of Bosnia bodes ill for the future, and suggests that the liberation of Kuwait was motivated by direct interest. The Serbs are counting on keeping what they have taken by force.

Responsibility lies not only with government and the armed forces of Serbia. All governments which have aided or abetted war crimes are also guilty of "non-assistance" to the victim. American interest, so far, is limited to the airdropping of food and medical supplies over Bosnia's capital Sarajevo, much of which apparently did not reach the trapped Moslem inhabitants.Although one may argue that the arms embargo helped, in a way, to limit the hostilities, it adversely affected the weaker party and was, thus, discriminatory towards the Bosnian Moslems. The Scrbs, in the meantime, achieved their twin goals of altering the demographic reality and redrawing the frontiers. Moreover, the changes are taking place through a ruthless genocide, nothing comparable to Iraq's attack on Kuwait.

The big losers are the Bosnian Moslems, who are in the bitter role of "Europe's Palestinians." There is no doubt that there is an ethnic cleasing in Bosnia. In fact, ethnic cleansing is very much with us, not only in former Yugoslavia, but also in Palestine/Israel. The latter case is actually the mother of ethnic cleasing in the post-World War II period. Before the Zionists came and founded their own state there, Palestine was well inhabitcd. That was already noted even by a number of Europeans, who visited the land of the Bible and went up and down the country in all directions and noted down the names of the many hundred Arab villages. Before, during and after the 1948 
war, the Zionists expelled hundreds of thousands of Palestinians. The Palmach, Haganah, Irgun and Stern did everything to encourage them to flee. ${ }^{11}$ The year Israel was created, the Zionists owned only 6 percent of the land. The rest was added through war, occupation, and ethnic cleansing. This transformation came about after a prolonged and tragically successful invasion of an alien people under Western, principally American, auspices. The result was the expulsion of most of the people whose country it was.

Further, Israel seized Washington's war drive to increase its garrisonstate brutality in the occupied territories, southern Lebanon, and behind the Green Line. The repressive measures have produced serious human rights violations, including deportation, denial of the right to return, destruction of dwellings, general ill-treatment, torture under detention, mass arrests, the transformation of the historical landscape, pillage of cultural sights, and interference in education.

The United States has a special responsibility for financing the settlements for the new immigrants from the former Soviet Union. Israeli leadership has a nightmare: an Arab majority even in "Greater Israel". East Jerusalem is one of the important targets. The United States, which has not openly supported Israel's claim to the whole of Jerusalem, did not oppose it in any concrete manner. As the Soviet Jews pour in, the United States looks the other way and releases loans in the hope that the money will be used within the "Green Line." This armistice line of 1948 is not a legal designation, and the Israelis have moved it in their minds to include East Jerusalem. But the policy of settling the new immigrants anywhere may be the cause of another clash. Not only the Arabs will find it more difficult to accept the permanent loss of their territories, but also the Palestinian exodus to open room for the newly-arriving Jews will swell the refugee camps in the neighbouring states. The United States has great responsibility in the turning of the occupation into a continuing fact.

In comparison to America's delayed and token interest in the fate of the Bosnian Moslems and tacit or active support of ethnic cleansing in Palestine, the American presence in Somalia has been presented as a life-saving mission launched with the best of motives. How did a country which has not exhibited altruistic intentions in many other cases become so charitable now? Why does a Somali civil war and famine demand military intervention when the tragedy in Bosnia has failed to attract similar attention for so long? The United States again appears to be extremely selective in its dispensation of humanitarian concern. The United States might have sent its troops to the Hom of Africa to give a demonstration of American "leadership." Promoting

11 John Quigly, Palestine and Israel:A Challenge to Justice, Durham, Duke University Press, 1990, pp. 82-86. 
Western intervention also helps "legitimize" interventions of the past by implication.

Although Somalia is one of the rare countries in Africa which is limguistically, religiously and ethnically homogenous, it does not exist as a single entity any longer. It has become a mosaic of clan-ruled regions. In spite of the homogeneous population, it was always the clan system that defined the society. The defeat in the disastrous Ogaden War, and the overthrow of the Siad Barre régime (1969-1991) led to a further rejection of the centralized authority. The result was a civil war among warlords, whose supporters killed and looted while the people faced a famine. A brilliant suggestion by Mohammed Sahnoun, the U.N. Secretary-General's special envoy, who enjoyed deep respect among the Somalis, to distribute salaries and uniforms to the local militias in order to disciple them, was not implemented.

When the United States intervened, the worst part of the famine was over. The reasons for American intervention may be summarized as follows: to prove that the U.N. could not function without U.S. involvement; to create a precedent for selective future interventions; to gain a foothold near the strategic Bab el-Mandeb; to be present in the Horn of Africa where Sudan pursued an Islamist policy towards its southern citizens as well; to bolster the Pentagon budget; and to back up the U.S. Continental Oil Company interested in oil in the northeastern part of the country.

\section{The Sidra Affair, the Lockerbie Case and Legality:}

The U.S. administration announced sanctions against Libya on alleged grounds that Libyan leadership was involved in terrorist attacks. The "evidence" in the bombings in Rome, Vienna and Berlin is far from being conclusive. The U.S. used the dispute over the Gulf of Sidra, which is a legal issue, to overthrow and/or kill the Libyan leader. The American attack as well as the attempt to kill the head of a government or state are both against international law. Moreover, the accusations that the two Libyan nationals were responsible for the atrocity over Lockerbie remain unsubstantiated, unproven and unconvincing. More importantly, the United States has come to use, or abuse, the United Nations as a means to punish countries with policies that contradict American interests. In respect to Libya, like the Iraqi case, double standards have been applied.

Explosions near El-Al offices in Rome and Vienna had caused the death of innocent people, including five Americans. The ex-President Reagan ordered that all Americans living in Libya leave the country, that all Libyan assets in American banks be frozen, and that two aircraft carriers be dispatched to the Gulf of Sidra. With the addition of a third naval force, the U.S. administration decided to penetrate the Gulf of Sidra and thereby 
precipitated a military conflict that caused the destruction of two Libyan naval crafts, a missile site and the death of Libyan sailors.

An explosion on a TWA jet killed another four Americans, and a similar attack at a West Berlin discotheque killed two more. The U.S. Government again blamed the Libyan leadership for this, and ordered two carriers back to the Gulf of Sidra. The latter destroyed Libyan radars, and killed about 40 people, wounding close to 200 , mostly civilians.

With these actions, President Reagan had provoked a military conflict expecting a Libyan defeat to be followed by a coup against the present government in Tripoli. The U.S. 6th Fleet and its aircraft penetrated the disputed waters of the Gulf of Sidra, and held hostile maneuvers near the Libyan oil installations. The United States seems to have expected the whole Libyan air force to become engaged with the American fleet and face defeat, causing a change of government.

It may be remembered in this connection that the U.S. has an "air defence identification zone" around its borders. Any unidentified object will be intercepted and will probably be destroyed. The U.S. will never tolerate a foreign state to maneuver or indulge in hostile air operations right near its strategic or economic facilities. It may not accept the Libyan assertion that the Gulf of Sidra is an "inland water", but this is purely a legal matter, to be decided in a peaceful way. American attack violates Articles 2/3 and 2/4 of the U.N. Charter, and Article 33 expects the exhaustion of all peaceful means. There is also the doctrine of "historic waters", which entitles a state to draw a closing line even if it exceeds otherwise internationally recognized criteria. The U.S. also made use of the same doctrine.

If the reason for armed intervention was the alleged sponsorship of terrorism, this could also have been submitted to the judgement of the World Court, as so proposed by Libya itself. The American executive did not agree to that because it apparently wanted to use both disputes as pretexts to provoke the Libyan leadership into a military conflict. It should be added here that the Italian and Austrian ministers of Interior stated that Gaddafi was not responsible for the attacks in Rome and Vienna, and the West German police rejected a link between Libya and the discotheque bombing.

These events served as pretexts for drastic military action against Libya. In one instance, Gaddafi's residence, in the midst of civilian quarters, was also bombed, killing an adopted baby daughter. An attempt to kill a head of state or government is against The Hague Regulations (1907), the Army Field Manual on the law of warfare (1956) and the American Executive Order prohibiting assassinations. 
In the opinion of some legal experts, American (and British) accusations against Libya, in connection with the explosion and crash (1988) of a PanAmerican aircraft in Lockerbie (Scotland), also emanate from political preferences and are deprived of acceptable legal basis. ${ }^{12}$ The United States secured several U.N. Security Council resolutions, using its overwhelming influence in coercing other members to vote in favour.

Libya complied with the terms of the Montreal Convention (1973), which elaborates on safety in air travel and communications. It instituted criminal proceedings against two suspects, who are its citizens. It has not extradited them, there being no extradition treaty in force between it and the United States (and Britain) and no basis for the extradition of the accused. The United States violated international law by refusing to turn over to Libya whatever evidence it might have.

The UNSC Resolution 748 (1992) was passed with five abstentions, China being one of them. But Article 27/3 of the U.N. Charter requires the affirmative votes of the permanent members. It also states that a party to a dispute shall abstain from voting. On the basis of these reservations, one may assert the illegality of the U.N. decisions.

Without underestimating the seriousness of the incident which caused the loss of innocent lives, the rigid American position is based on the logic of force. The two accused Libyan nationals have a basic human right to a fair trial before an impartial court. Not power politics, but the rule of law should be supreme. The U.S. is violating the U.N. Charter by closing the door of resort to a peaceful solution of disputes. Further, although the members consider the Security Council as acting in their name (Article 24/1), the same organ is expected to conform to the purposes and the principles of the United Nations (Article 24/2). While the United States is orchestrating the Security Council (the least democratic of the U.N. organs), General Assembly (the most democratic) is kept powerless.

A new world order respectful of the rule of law, on the other hand, implies that the U.N. Security Council should act in conformity with the principles of international law and justice. The United States used its power and influence to induce others to vote in favour. Under American leadership, the Security Council, in sanctioning Libya, exceeded its powers.

\footnotetext{
12 Francis A. Boyle, Memorandum of Law on the Dispute Between Libya and the United Kingdom over the Lockerbie Bombing Allegations, manuscript, 1992; Türkkaya Ataöv, The Lockerbie Case: Sanctions against Libya and Legality, Ankara, Zirve Ofset, 1992.
} 


\section{The Latin American Scene:}

Although the United States is trying to build a reputation for itself as the protector of persecuted minorities, such as the Bosnian Moslems, the worst atrocities in the Latin American world were carried out in the domains of U.S. influence and control. ${ }^{13}$ The United States has been tormenting the countries below its southern frontier for more than a century. Up until the Cuban Revolution, the United States endeavored to isolate Latin America from changes occurring in the world and preserve the status quo. In the decade after the Cuban Revolution, Washington tried to put a sanitary cordon around that régime. Since then, it gradually retreated from its unvaried hard-line in Latin America and introduced a differentiated approach according to the specific position of each country.

Revising its Latin American policy from time to time, Washington follows various patterns such as "Big Stick," "dollar diplomacy," "good neighbour" and "new frontiers" policies. But these changes stay within the limits of two fundamental approaches: a hard line, characterized by intervention, pressure and alliances with dictators and cooperation as a more flexible means of influence and expansion. Most recently, it has acted to destabilise the situation in Panama, Nicaragua and Cuba.

The United States opposes change if it does not conform to its own interests. Changes are resisted even if some states are run by gangster cliques. Manuel Noriega was removed by invasion when he stole the 1989 election that had been won by the U.S.-backed Guillermo Endara. The same Noriega had stolen the 1984 election with more violence but he was then America's ruffian, working closely with the CIA and opposing Arias, a "dangerous nationalist." Former President Ronald Reagan had described Rios Mont, the Guatemalan dictator who had slaughtered thousands of his own countrymen and driven from their homes many more, as a man of great personal integrity totally committed to democracy.

The United States was widely condemned when it invaded Panama (1989), on the pretext that this isthmian country had impeded the operation of the Canal, that Washington was acting in self-defence against anticipated attacks on American personnel in Panama, and that it had acted to arrest General Manuel Noriega on drug trafficking charges.

The U.S. and Panama signed (1977) two new treaties concerning the Canal, replacing the former Isthmian Canal Convention (1903). One of the new treaties required the U.S. to turn over the control of the Canal to the

${ }^{13}$ For instance: Noam Chomsky, Turning the Tide: U.S. Intervention in Central America and the Struggle for Peace, Boston, South End Press, 1985. 
indigeneous authorities gradually, the final transfer to take place on the last day of 1999. The other treaty required the two countries to ensure that the Canal be accessible to the shipping of all.

Although then President Bush said that the American actions were meant to honour the commitments under the treaties, Panama had not breached its obligations, and the U.S. had no unilateral right to intervene militarily. The Canal was recognized as Panamanian territory. The U.S. could intervene only against entities other than Panama. Moreover, a "statement of understanding" (1977) between the former President Carter and General Omar Torrijos of Panama declared that the U.S. had no right to intervene in Panama's domestic affairs. The U.N. Charter and the Charter of the Organization of American States both prohibit such use of force.

As for self-defence, Panama could not wage a war against the U.S. It had not done so or was about to do it. The U.S. had no legitimate basis, but only pretexts for invasion. Such military intrusion to make an arrest also violates a state's sovereignty.

There is a coherence between the U.S. assertion of self-defence and justification of American military action in other events. The U.S. invaded Grenada (1983) arguing that this petty Caribbean state was going to invade neighbouring countries. It forcibly stopped (1985) an Egyptian plane over the international waters of the Mediterranean, and kept people on board in custody on grounds that they hijacked a cruise vessel. It bombed (1986) Libyan targets claiming that the latter country had planned attacks, an assertion still unsubstantiated. The U.S. claim in respect to Panama agrees with the earlier unproven accusations. Self-defence, on the other hand, is permissible only in response to "armed attack".

The United States continues the Cold War in the Caribbean although it has melted elsewhere. The Havana régime ceased all aid to insurgents in Latin America, but the United States, which in the past carried out military maneuvres near the island and even supported armed interventions, is still exerting pressure on other countries to curtail commerce with Cuba. Such a policy will bring only suffering to the Cuban people.

It is the Cuban people, just like the peoples of Iraq and Libya, who are suffering from a burden imposed on them from outside. One U.S. president after another has made no secret that American policy aims to catalyze a chain reaction in that country: trade limitations for more than three decades will cause economic decline, bringing along inflation and shortages; declining economic conditions will fead social unrest, with support from the northern neighbour who wishes to repossess its "lost colony". 
American policy has been basically the same when Cuba carried out a new Agrarian Reform Law (1959), which took away almost all of the arable land owned by the foreigners. Washington broke diplomatic relations with Havana a day after Cuba formally charged, before the United Nations, that the United States was planning to invade the island. Just a few months later, in early 1961, an invasion force indeed attacked the Bay of Pigs. After the defeat of this force, a total U.S. embargo against trade with Cuba went into effect. It continued even after the dissolution of the Soviet Union. It is now disrupting the lives of the second generation of Cubans.

\section{Conclusion:}

The current tendency to overemphasize the centrality of anarchy and violence in international politics is neither realistic, nor useful. Such demotion belittles the role of interdependence, hence plurality and the need for democracy in the world system. Although interdependence is not the opposite of anarchy, it underlines harmonious as well as conflicting interests, each gaining from this relationship, but nevertheless struggling for the distribution of these gains. We are all mountain climbers attached to a rope. The world is undergoing rapid change, and no country, including the United States, can expect to retain the status quo for a long time. All countries must learn to apply universally recognized principles. Military superiority cannot, in the long run, give a political advantage to any quarter. Maximum humanization of politics should be central to a new way of thinking.

It seems that the future of world politics will be determined by the Global North-Global South paradigm. The countries of the South, which make up three-quarters of humanity and characterized by general poverty, should act like a collective group on the global scene. They may differ in the degree of achievement, size and structure or some may fall in the gray area in the North-South division, but they share common traits such as being powerless in the world arena. The North, which may have some pockets of poverty as well, is indifferent or even against the rights, views, aspirations and interests of the Global South, otherwise known during the Cold War as the Third World.

The changes in Eastem Europe and the former Soviet Union have made the North-South contradiction even sharper. While the old East-West axis is being replaced by the dichotomy between the North and the South, the latter knows that its freedom of movement is now restricted. The countervailing weight of the Eastern bloc no longer existing, the United States has started setting the agenda of the U.N. Security Council, which now has a new role mostly in the service of the North. This is a long way from what the situation was only a few years ago. 
The new U.S. mid-intensity doctrine falls in line with the renewed assertion of pax Americana. The latter demands the use of force to protect U.S. interests whereever threatened. In fact, there is no end to possible threats to U.S. interests. There will always be some sort of disorder in the Third World, which, in the opinion of official American circles, will threaten to jeopartize the interests of that country. The United States now utilizes peaceful means much less, and selectively resorts to concentrated firepower. Likewise, the reference to "respect for human rights" is really meant for U.S. adversaries.

Especially the embargoes imposed, on U.S. insistence, on some Third World countries cause humanitarian tragedies and undermine the legitimacy of the United Nations as a guarantor of human rights and the rule of law. Such sanctions, as weapons obviously aiming at masses, attack, above all, those segments of society most vulnerable, that is, infants, the elderly, the chronically ill and the emergency medical cases, and can be considered as "crimes against humanity" in the Nuremberg sense. They resemble the neutron bomb, designed to kill human beings. The people of selected Third World countries, subjected to grueling tests, are trying to endure them. Embargoes should be brought to an end, and never again applied on peoples, no matter in which country, friendly or foe. 